\title{
GLOBALIZATION VS. ECONOMIC GROWTH IN NEW COUNTRIES OF THE EUROPEAN UNION
}

\author{
Stanisław Swadzba ${ }^{1, a, *}$ \\ ${ }^{1}$ University of Economics in Katowice, 40-287 Katowice, ul. 1 Maja 50, Poland \\ ${ }^{\mathrm{a}}$ stanislaw.swadzba@ue.katowice.pl \\ *Corresponding author
}

Cite as: Swadzba, S. (2019). Globalization vs. economic growth in new countries of the European Union. Ekonomicko-manazerske spektrum, 13(1), 1-11.

Available at: dx.doi.org/10.26552/ems.2019.1.1-11

\begin{abstract}
The main goal of this paper is to show the level of globalization, its changes and the rate of economic growth that have taken place in the new Member States of the European Union (EU), exactly the former socialist countries (EU-11). The aim is also to present the impact of globalization on economic growth in these countries. The following research methods were used: historical, literature, descriptive analysis and simple statistical methods. Statistical data used in this paper come from KOF (index of globalization and its three subindices), Eurostat and Human Development Reports (United Nations Development Programme). The time range of research is 1990-2018. The main conclusions of the study are as follows: 1.The level of globalization of this group of countries has increased significantly; 2. The largest increase took place in countries where the level of globalization at the starting point was the lowest, and the lowest in the most globalized countries; 3. As a result, the differences between individual countries have significantly diminished (we can see the convergence); 4. The current level of globalization of these countries is mainly the result of the combined action of both systemic transformations and the process of integration with the EU. 5. The rate of economic growth in these countries is rather high, much higher than in the old EU. As a result, GDP per capita increased significantly; 6. A small positive correlation exists between the degree of globalization and GDP per capita in these countries; 7. The positive impact of globalization on economic growth in the analysed group of countries was also noted.
\end{abstract}

Keywords: globalization, economic growth, new European Union countries

JEL Classification: F60

\section{Introduction}

Globalization is an extraordinary concept that burst upon the world relatively recently, but processes of globalization have been happening for centuries (James and Steger, 2014). It has a very long history. Globalizing processes have touched many people and influenced the development of individual societies, as well as the world as a whole (Bentley, 2004). It is certainly one of the major socio-economic processes of recent decades.

There is no agreement in the literature on the concept of globalization. "It means different things to different people" (Martens et al., 2010). According to A. Scholte, globalization can be understood as: internationalization, liberalization, universalisation and westernisation (Scholte, 2008). It is also recognized as a higher, more advanced and complex stage in the process of economic internationalization, and hence the continuation of what had already 
happened. Globalization is only - as most economists think - accelerating the long-standing internationalization of the economic process. Some add that this is an exceedance of a certain threshold. If internationalization meant the development of economic relations between independent national economies, then globalization would mean such intensification of relations that all global national economies become more or less interdependent. Globalization is also often referred to as the growing integration of national economies (through international trade and foreign direct investment). Markets and production become increasingly interdependent. Globalization can also be defined as the process of even closer integration of national economies. This is because it is a process of eliminating border barriers to market functioning. The consequence of this is the process of integrating the world economy (Swadzba, 2017).

The process of globalization covers more and more countries. We all live in the globalizing world. In principle, there is no country that would not be affected. However, the level of globalization of individual countries is diverse. We say, some of them are more, some less globalized. What does it mean? On what basis can we say so? The answer is - we have to measure globalization. The purpose of measuring globalization is to demonstrate the degree of globalization in individual countries and to capture this process over time. Measuring globalization is very important. Without doing so, it is impossible to assess the severity or benefits of its effects, how it should be managed (if it is manageable) etc. Globalization there are no doubts - can be better understood by measuring it (Dreher et al., 2010; Martens et al., 2014).

When attempts to quantify globalization are made, globalization is interpreted as internationalization. This term refers to a growth of transactions and interdependence between countries. The scores mainly relate to them. However, to assess the extent to which any country is more or less globalized we require much more than employing data on flows of trade and foreign direct investment. The idea of globalization includes also social, cultural, political and ecological factors. They are also very important (Martens and Rotmans, 2005; Martens et al., 2010). A pluralistic approach to globalization is needed.

Representatives of different scientific disciplines are interested in many aspects of globalization. One of them is the impact of globalization on economic growth. Globalization is expected to promote economic growth for many reasons. First, international knowledge spillovers will certainly help to increase economic growth. Second, entrepreneurs have access to larger potential markets in open than closed economies. Third, entrepreneurs may well exploit comparative advantages and receive gains from specialization during globalization. Production will become more efficient and increase a country's economic growth (Grossman and Helpman, 2015).

The historical evidence on the relationship between them has been shown by Crafts (2004). The results of many empirical studies suggest that globalization has extended positive effect on economic growth. Globalization indeed promotes growth (Dreher, 2006). Several studies have shown that more globalized countries are also more sustainable, and in general also healthier (Martens et al., 2010). The evidence shows that globalization has spurred economic growth, promoted gender equality and improved human rights. It increased, however, income inequality (Dreher and Gaston, 2008; Potrafke, 2015). There has been a clear process of globalization convergence. Some studies try to show whether the globalization brings about the convergence in per capita income (Villaverde and Maza, 2011). Other studies suggest that rather developing instead of industrialized countries enjoy economic growth during 
globalization ${ }^{1}$. Hayaloglu (Hayaloglu et al., 2015) show, that the impact of globalization on economic growth varies depending on the level of development of individual countries. The latest research (Gygli et al., 2019), using the new KOF Globalisation Index, distinguished de facto and de jure globalization and show that these have different effects ${ }^{2}$. The attempt to verify some of these theses will be taken in this paper.

The main goal of this paper is to present the changes in the level of globalization and economic growth. The aim is also to show the relation of globalization vs. economic growth. The research covered 11 Central and East Europe (CEE) countries, namely: Bulgaria, Croatia, the Czech Republic, Estonia, Lithuania, Latvia, Poland, Romania, Slovakia, Slovenia and Hungary. They are called "post-socialist countries" or "former socialist countries". After World War II, there was a centrally planned economy system. At the turn of the 1980s and 1990 s, a systemic transformation began there. The process of integration with the EU has also begun in these countries. They quickly adapted to the EU requirements and became members of the EU. First of all: the Czech Republic, Estonia, Lithuania, Latvia, Poland, Slovakia, Slovenia and Hungary (1.05.2004), next Bulgaria and Romania (1.01.2007), and last Croatia (1.07.2013). They belong to the so-called "new EU"3 . Due to the specificity of these countries and their number, the abbreviation "EU-11" will be used in this paper.

\section{Methodology}

The following research methods were used: historical, literature, descriptive analysis and simple statistical methods. Statistical data used in this paper come from KOF (index of globalization and its three sub-indices), Eurostat (real GDP average annual growth rate and GDP per capita) and Human Development Reports - United Nations Development Programme (Human Development Index /HDI/ and average annual HDI growth). The time range of research is 1990-2018.

The basis for considering the changes in the level of globalization will be the KOF Index of Globalization developed in 2002. It was introduced by A. Dreher (2006) and updated in Dreher et al. (2008). The second revision of this index dates from 2018 (Gygli et al., 2019). It is developed and published annually. In addition, the above index has been developed for earlier years. The other globalization indices do not have these features: first globalization index developed by A.T. Kearney and the "Foreign Policy" in 2001 (Kearney/Foreign Policy, 2001), CSGR (Centre for the Study of Globalization and Regionalization at the University of Warwick in the United Kingdom) Globalization Index (Lockwood, 2004; Lockwood and Redoano, 2005), Maastricht Globalisation Index (Martens and Zywietz, 2006; Martens and Raza, 2009; Figge and Martens, 2014), New Globalisation Index (Vujakovic, 2010) and many others (Martens et al., 2014). To describe the current level of globalization, the $2018 \mathrm{KOF}$ Index of Globalization (rankings for the year 2015) was adopted, and the previous indices were used to show the changes.

The KOF index has three dimensions, namely: economic globalization, social globalization and political globalization. As a result, in addition to the global index of globalization, 3 sub-

\footnotetext{
${ }^{1}$ Bergh and Karlsson (2010) present evidence for OECD countries. Samini and Jenatabadi (2014) for countries of the Organization of Islamic Cooperation (OIC).

${ }^{2}$ Economic growth increases when de jure economic and political globalization and de facto social globalization are more pronounced.

3"New EU" also include Cyprus and Malta. These two countries also joined the EU on May 1, 2004. These countries will not be the subject of our deliberations.
} 
indices were created. Each of them is calculated on the basis of several indicators. In addition, each is assigned a specific weight ${ }^{4}$. These indices will also be used in this paper.

Choosing the KOF index does not mean that it is free of any weaknesses. It is criticized by opponents of quantitative measuring of globalization. But such a measurement also has its advantages $^{5}$. Accepting the measurement of globalization, it was considered that in the case of the KOF index, these disadvantages are the least important and the advantages are the most. Many researchers, who often use this index in their works, are of the similar opinion (Gozgor, 2018). The new revision of this index ${ }^{6}$ will certainly make it even more useful in the future and will contribute to the development of research in this field.

\section{Results}

The latest KOF globalization index (2018), as well as sub-indices, for the EU-11 countries and their place in the world ranking, is given in Table 1.

Table 1: 2018 KOF Index of Globalization (EU-11)

\begin{tabular}{|c|c|c|c|c|c|c|c|}
\hline \multicolumn{2}{|c|}{ Globalization Index } & \multicolumn{2}{|c|}{ Economic Globalization } & \multicolumn{2}{|c|}{ Social Globalization } & \multicolumn{2}{|c|}{ Political Globalization } \\
\hline 12. Hungary & 84.20 & 8. Estonia & 84.31 & 22. Estonia & 82.65 & 21. Poland & 92.15 \\
\hline 15. Czech Rep. & 83.41 & 10. Hungary & 83.02 & 25. Lithuania & 80.86 & 23. Hungary & 91.99 \\
\hline 20. Estonia & 81.97 & 13. Czech Rep. & 81.69 & 26. Slovenia & 80.85 & 24. Romania & 91.90 \\
\hline 21. Slovak Rep. & 80.74 & 16. Latvia & 81.01 & 31. Croatia & 79.50 & 29. Czech Rep. & 90.22 \\
\hline 25. Slovenia & 79.76 & 20. Slovak Rep. & 79.05 & 33. Czech Rep. & 78.32 & 38. Bulgaria & 87.08 \\
\hline 26. Bulgaria & 79.52 & 21. Bulgaria & 77.77 & 35. Slovak Rep. & 78.03 & 42. Croatia & 85.43 \\
\hline 29. Croatia & 79.04 & 27. Lithuania & 76.38 & 36. Hungary & 77.58 & 44. Slovak Rep. & 85.15 \\
\hline 30. Lithuania & 78.78 & 30. Slovenia & 75.66 & 43. Latvia & 76.31 & 50. Slovenia & 82.77 \\
\hline 31. Poland & 78.72 & 38. Croatia & 72.20 & 47. Poland & 75.15 & 59. Lithuania & 79.10 \\
\hline 33. Romania & 77.88 & 39. Romania & 71.68 & 52. Bulgaria & 73.71 & 61. Estonia & 78.94 \\
\hline 39. Latvia & 75.42 & 46. Poland & 68.87 & 70. Romania & 70.05 & 95. Latvia & 68.93 \\
\hline
\end{tabular}

Source: $(K O F)$

Hungary is the most globalized country according to KOF (2018), followed by the Czech Republic and Estonia. These three countries are at the top twenty of the world ranking. The Slovak Republic came in 21st place. These four countries reached over 80 points. They are followed by Slovenia, Bulgaria, Croatia and Lithuania (also in the third "10"). The lowest position in this group of countries was taken by Poland, Romania and Latvia (all in the fourth "10"). The difference between the most and the least globalized country is 8.78 points.

Estonia is ranked first in the economic globalization. Hungary was second. These two countries from the first " 10 " are followed by the Czech Republic (13) and Latvia (16). All of them gained over 80 points. They are followed by Slovak Republic (also at the top twenty of the world ranking). The worst in this ranking - on the 46th place with about 69 points only was Poland (15.44 points less comparing to Estonia). The difference between the most and the least globalized country in the economic globalization ranking is much bigger than in overall ranking.

In ranking of social globalization, Estonia also took first place. Lithuania was second, much better than in other rankings. They are followed by Slovenia (almost the same number of points as Lithuania). They reached over 80 points. Poland - with 75 points - is on the 46th

\footnotetext{
${ }^{4}$ Detailed information on the methodology for calculating the index see: (KOF).

${ }^{5}$ It is well-regarded in the literature on the advantages and disadvantages of globalization measurment (Caselli, 2008; Dreher et al., 2008; Dreher et al., 2010; Zagora-Jonszta, 2017).

${ }^{6}$ This revision distinguishes between de facto and de jure measures along the different dimensions of globalization. It also distinguishes trade and financial globalization within the economic dimension of globalization and use time-varying weighting of the variables. The new index is based on 43 instead of 23 variables in the previous version (Gygli et al., 2019).
} 
place. Behind Poland only Bulgaria and Romania. The EU-11 countries are not at the top in this ranking (none at the top "20"). The difference between the most (Estonia) and the least globalized country (Romania) is 12.6 points.

More diverse - compared to the earlier sub-indices - is the ranking of political globalization. Poland is the most globalized country. Hungary is second, next Romania and Czech Republic (over 90 points). The EU-11 countries occupy in this ranking also lower places. The above highest ranked countries are in the third "10" of the world ranking. The remaining countries are much further. At the end, there are the Baltic States. Last Latvia was only on 95th position with 23.22 points less than Poland (the biggest difference).

The KOF provides the information that allows us to identify the changes that have taken place in the level of globalization in EU-11 since the 1990s. It is shown in Table 2.

Table 2: KOF Index of Globalization 1990-2018 (UE-11)

\begin{tabular}{|c|c|c|c|c|c|c|}
\hline Country & 1990* & 1995 & 2000 & 2005 & 2010 & 2018 \\
\hline Bulgaria & 38.34 & 54.15 & 63.72 & 67.32 & 71.4 & 79.52 \\
\hline Czech Rep. & 65.77 & 70.83 & 78.49 & 84.07 & 84.27 & 83.41 \\
\hline Estonia & 42.56 & 61.96 & 72.48 & 76.6 & 78.82 & 81.97 \\
\hline Croatia & 39.64 & 42.73 & 62.57 & 73.23 & 75.53 & 79.04 \\
\hline Hungary & 58.82 & 75.13 & 81.07 & 85.48 & 87.07 & 84.20 \\
\hline Lithuania & 35.17 & 49.1 & 62.51 & 70.19 & 72.06 & 78.78 \\
\hline Latvia & 37.18 & 48.23 & 57.22 & 67.42 & 69.33 & 75.42 \\
\hline Poland & 49.24 & 66.69 & 72.51 & 78.51 & 80.1 & 78.72 \\
\hline Romania & 34.13 & 50.98 & 62.07 & 67.13 & 73.62 & 77.78 \\
\hline Slovak Rep. & 56.85 & 63.83 & 74.29 & 82.9 & 84.75 & 80.74 \\
\hline Slovenia & 38.44 & 51.35 & 66.24 & 75.19 & 76.87 & 79.76 \\
\hline
\end{tabular}

*Estonia, Croatia and Slovenia - 1991, Czech Republic and Slovak Republic - 1993.

Source: $($ KOF $)$

The increase in the level of globalization took place in all the countries. In the period 1995 2018 (data from the years 1990-1994 are not available for all countries) the index increased most in Croatia: by about 36 points, next in Lithuania (by almost 30 points), Slovenia, Latvia, Romania and Bulgaria (by over 25 points). The lower increase was in Estonia (by 20 points), next in the Slovak Republic, the Czech Republic and Poland (by less than 20 points). The lowest in Hungary (by less than 10 points) ${ }^{7}$. In terms of percentage points the biggest leap was made also in Croatia (85\%) and Lithuania (60\%), next in Latvia, Slovenia, Romania (about 50\%) and Bulgaria (less than 50\%). The changes in other countries were smaller (from about $30 \%$ in Estonia to only $12 \%$ in Hungary). The largest changes were recorded by countries with a low level of globalization in the base year, and the lowest in the most globalized ones. As a result, the differences between them decreased. If in 1995 the difference between the most and the least globalized was 32.4 points, it dropped to 23.85 in 2000, 23.41 in $2005,17.74$ in 2010 and 8.78 points in 2018 . The convergence in the levels of globalization is evident.

The largest changes occurred in the first transition period (1990-1995). Although the data for this period are not fully comparable, one can notice a significant increase in the KOF globalization index. The largest, and in a shorter period, was recorded by Estonia (by 19.4 points). Only a slightly lower leap was recorded by Poland and Hungary (these two countries decided on a shock transformation too). Romania and Bulgaria, which in the initial period chose this type of transition, were also among the leaders. The globalization index in Croatia

${ }^{7}$ Such changes, with the exception of Cyprus and Malta (also new EU countries), were not recorded by other EU countries (KOF). 
only increased slightly (which can be explained by the war in the Balkans), as well as in the Czech Republic and Slovakia (in these countries in a shorter period).

In the second half of the 1990s, the largest increase (by 20 points) was recorded by Croatia and Slovenia. Lower growth was recorded by Bulgaria and Romania (slowdown of the transition process), and above all Poland and Hungary (increase by 6 points).

The first years of the 21 st century are the period of completion of the necessary adaptation processes to the requirements of the EU membership, and at the same time the end of the systemic transformation for most countries. In the years 2000-2005, the level of globalization was growing in all the countries. These changes are not so large, and there are no such huge differences between the EU-11 countries. The largest increase (by about 10 points) occurred in Croatia (further catching up) and Latvia (a smaller increase in the index of globalization in previous years). The smallest increase (by about 4 points) was recorded by Bulgaria, Estonia and Hungary. Even smaller increase in the globalization index took place in 2005-2010. For most countries, this was an increase of about 2 points. The exception was Bulgaria (increase by 4 points) and Romania (increase by 6.5 points), these are two countries that joined the EU later.

The second decade of the 21st century recorded a further slowdown in the rate of globalization growth in the analysed group of countries. A slight decrease was recorded in Slovakia (4 points), Hungary (almost 3 points), Poland (1.4 points) and Czech Republic (less than 1 point). The increase was recorded in Slovenia, Estonia (about 3 points), Croatia (3.5 points) and Romania (slightly above 4 points). The globalization index increased the most in Latvia, Lithuania (by around 6 points) and Bulgaria (by about 8 points).

The rate of economic growth that is measured by an increase in the real GDP of EU-11 countries in the years of 1996-2017 is presented in table 3.

Table 3: Real GDP average annual growth rate (\%)

\begin{tabular}{|c|c|c|c|c|c|}
\hline Country & 2017 & 1996-2000 & 2001-2010 & 2011-2017 & 1996-2017 \\
\hline EU (28) & 2.4 & $2.9^{\mathrm{a}}$ & $1.4^{\mathrm{a}}$ & 1.5 & 1.8 \\
\hline Bulgaria & 3.8 & -0.2 & 3.9 & 2.2 & 2.7 \\
\hline Czech Rep. & 4.4 & 1.9 & 3.4 & 2.2 & 2.7 \\
\hline Estonia & 4.9 & 7.6 & 3.8 & 3.7 & 4.6 \\
\hline Croatia & 2.9 & 3.4 & 2.8 & 0.8 & 2.2 \\
\hline Hungary & 4.1 & 3.0 & 2.0 & 2.0 & 2.3 \\
\hline Lithuania & 4.1 & 6.4 & 4.5 & 3.6 & 4.8 \\
\hline Latvia & 4.6 & 5.2 & 4.1 & 3.5 & 4.1 \\
\hline Poland & 4.8 & 5.4 & 3.5 & 3.3 & 4.5 \\
\hline Romania & 7.0 & -0.4 & 4.3 & 3.8 & 3.1 \\
\hline Slovak Rep. & 3.2 & 3.8 & 4.5 & 2.8 & 5.0 \\
\hline Slovenia & 4.9 & 4.3 & 2.6 & 1.4 & 2.7 \\
\hline
\end{tabular}

$\mathrm{a}-\mathrm{EU}(27)$

Source: (https://ec.europa.eu)

The average annual rate of the economic growth in all EU-11 countries in the years 19962017 was much higher as compared to the whole European Union (EU-28). The highest in the Slovak Republic (5\%), next in Lithuania, Estonia, Poland and Latvia (over 4\%). The lowest in Bulgaria, Czech Republic, Slovenia, Hungary and Croatia (less than 3\%). It was similar in particular decades except for the 1990s (Romania, Bulgaria and Czech Republic) and the second decade of the 21st century (Croatia). In 2017 real GDP increased most in Romania (7\%), next in Estonia, Slovenia, Poland, Latvia, Czech Republic, Hungary and Lithuania (4.94.1\%) The lowest increase was in Croatia, Slovak Republic and Bulgaria (less than 4\%). 
The high rate of economic growth of the EU-11 countries caused a decrease in the differences between the level of GDP per capita of these countries and the old EU countries. It is shown in table 4.

Table 4: GDP per capita (UE-11)

\begin{tabular}{cccc}
\hline Country & $\begin{array}{c}\text { GDP at market prices } \\
\text { (current prices, euro per } \\
\text { capita) }\end{array}$ & $\begin{array}{c}\text { GDP at market prices } \\
\text { percentage of EU-28 total } \\
\text { per capita, PPS, current } \\
\text { prices) } \\
\mathbf{2 0 1 7}\end{array}$ & $\begin{array}{c}\text { GDP at market prices } \\
\text { (percentage of EU-27 total } \\
\text { per capita, PPS, current } \\
\text { prices) } \\
\text { 1995 }\end{array}$ \\
\hline EU (28) & $\mathbf{2 0 1 7}$ & 100 & 100 \\
Bulgaria & 30,000 & 49.3 & 32 \\
Czech Rep. & 7,300 & 89.5 & 77 \\
Estonia & 18,100 & 78.8 & 36 \\
Croatia & 18,000 & 61.6 & 46 \\
Hungary & 11,800 & 66.8 & 51 \\
Lithuania & 13,900 & 78.4 & 36 \\
Latvia & 14,900 & 67.7 & 31 \\
Poland & 12,700 & 69.6 & 43 \\
Romania & 12,200 & 62.4 & $33^{\mathrm{a}}$ \\
Slovak Rep. & 9,500 & 85.1 & 47 \\
Slovenia & 20,800 & 76.2 & 75 \\
\hline a - 1996 & 15,600 & &
\end{tabular}

Source: (https://ec.europa.eu)

In 1995 the highest level of the GDP per capita as compared to the EU average (EU-27 = 100) was reported in the Czech Republic (it amounted to 77) and Slovenia (75). The lowest in Bulgaria, Romania and the Baltic states (about 1/3 of the EU average). In 2017, it was much higher in all countries. The highest in the Czech Republic (almost 90\% of the EU average) and the Slovak Republic (about 85\%), next in Estonia, Lithuania, Slovenia (less than 80\%) and Poland (almost 70\%). The lowest in Bulgaria (less than half of the EU average).

The greatest changes were observed in countries where the rate of economic growth was the highest and the level of GDP per capita rather low, i.e. in Estonia, Lithuania (an increase by over 42 percentage points - p.p.) and Latvia (an increase by almost 37 p.p.). A noticeably lower increase was reported by Slovenia (10 p.p.) and Czech Republic (12 p.p.). At the very beginning (1990th) the level of the GDP per capita in these countries varied, so it would be more objective to present the changes using an index that shows percentage changes. The highest value was reported in the Baltic States (an increase of almost 120\%) and Romania (by about 90\%). The lowest values were reported in Slovenia (13,5\%) and in the Czech Republic $(16,2 \%)$.

Comparing 1995 with 2017, it can be concluded that EU-11 countries have made good progress. However, the differences between these countries and the EU-28 average - as far as GDP at market prices per capita in euro (current prices) are concerned - is still high. In 2017 the average for EU-28 was 30,000 euro. From the EU-11 countries only Slovenia has exceeded 20,000 euro. Bulgaria and Romania haven't reached yet 10,000 euro.

The changes have also taken place in socio-economic development. Human Development Index (HDI) and average annual HDI growth in EU-11 countries are shown in table 5.

Table 5: HDI Index and average annual HDI growth (UE-11)

\begin{tabular}{cccccc}
\hline $\begin{array}{c}\text { Country } \\
\text { (HDI rank) }\end{array}$ & $\begin{array}{c}\text { HDI Index } \\
\mathbf{2 0 1 7}\end{array}$ & $\mathbf{1 9 9 0 - 2 0 0 0}$ & $\mathbf{2 0 0 0 - 2 0 1 0}$ & $\mathbf{2 0 1 0 - 2 0 1 7}$ & $\mathbf{1 9 9 0 - 2 0 1 7}$ \\
\hline Slovenia (25) & 0.096 & 0.73 & 0.68 & 0.23 & 0.58 \\
Czech Rep. & 0.888 & 0.86 & 0.80 & 0.42 & 0.72 \\
(27) & 0.871 & 0.63 & 0.79 & 0.44 & 0.64
\end{tabular}




$\begin{array}{cccccc}\text { Poland (33) } & 0.865 & 0.98 & 0.62 & 0.50 & 0.72 \\ \text { Lithuania (35) } & 0.858 & 0.33 & 0.87 & 0.58 & 0.59 \\ \text { Slovak Rep } & 0.855 & 0.33 & 0.83 & 0.44 & 0.54 \\ \text { (38) } & 0.847 & 0.33 & 1.15 & 0.53 & 0.69 \\ \text { Latvia (41) } & 0.838 & 0.89 & 0.68 & 0.26 & 0.65 \\ \text { Hungary (45) } & 0.831 & 1.14 & 0.75 & 0.40 & 0.80 \\ \text { Croatia (46) } & 0.813 & 0.26 & 0.80 & 0.61 & 0.59 \\ \text { Bulgaria (51) } & 0.811 & 0.11 & 1.18 & 0.25 & 0.54 \\ \text { Romania (52) } & & & & \end{array}$

Source: (Human Development Reports)

Slovenia is the most developed country according to Human Development Report (2018), followed by the Czech Republic and Estonia. These three countries are at the top thirty of the world HDI ranking. They are followed by Poland, Lithuania and Slovak Republic (in the fourth "10"). The lowest positions were taken by Bulgaria and Romania. The order is similar to the GDP per capita ranking.

The average annual HDI growth differs from country to country, but the differences were not significant. The increase in the level of HDI index took place in all countries, most in Croatia (0.8\%), next in the Czech Republic and Poland (about 0.7\%). The lowest increase was in Bulgaria, Lithuania, Slovenia, Slovak Republic and Romania (less than $0.6 \%$ ). The average annual HDI growth rate in individual decades differed significantly.

\section{Discussions}

The systemic transformation that began in this group of countries in the early 1990s was the main factor that contributed to the increase in their level of globalization. It enabled the exit from a closed block, the exit to the world, which contributed to the growth of international trade, foreign direct investment, indirect investments, etc. It was previously limited or even impossible from political reasons. These indicators, as well as the level of restrictions (which was also limited) in international exchange, are used to calculate the economic degree of the globalization dimension. It was also influenced by the increase of international personal contacts (mainly tourism development), information flow and cultural proximity, which determines the level of social globalization. It also increased the number of connections with other countries, participation in international organizations, concluded international treaties and thus, also had an impact on its political dimension ${ }^{8}$. As a result, the globalization index of the countries that joined the process increased significantly.

However, the process of systemic transformation in this group of countries varied. Hence the differences in the level of globalization. In countries that did it radically, the globalization index grew faster. The countries that were successful in implementing the systemic transformation (Hungary, the Czech Republic, Slovakia, Poland, and Estonia) soon achieved a relatively high level of globalization and maintained a high position in the globalization ranking. The countries of "late transformation" (Bulgaria, Romania, Croatia) had a low level of globalization at the starting point, were catching up with the leaders for a long time and mostly still have a lower degree of globalization?

It is worth adding that the countries of CEE outside the EU-11 are in most cases countries of "late" or even still "unfinished" transformation. They had a low level of globalization at the

${ }^{8}$ These are the main indicators used to calculate the level of globalization for most indexes, including KOF.

${ }^{9}$ This division is based on indicators of the progres of market reforms developed by EBRD (EBRD). 
starting point for the systemic transformation. Despite the very rapid increase in the level of globalization, they are still lagging behind the EU-11 countries. In the 2018, KOF Index Globalization ranking none of them is ahead of any EU Member State (KOF).

Economic integration has strengthened globalization. "The four EU freedoms" have undoubtedly contributed to increased flows of goods, services, capital and people. The common market played an important role here. The economic aspect of globalization has been increased, as well as the social (through personal contacts) and political (the position of these countries in the world) increase. The processes caused by systemic transformation intensified. It is true that after the accession to the EU, the rate of growth in the level of globalization has been slowed down, but it must be remembered that the liberalization of international exchange appeared already in the pre-accession period well before joining the EU. There were no major changes immediately after the accession. Therefore, we cannot say that integration with the EU has inhibited the globalization process in these countries. The relationship between integration and globalization is obvious. The most globalized countries entered the EU first. Countries with a lower globalization level joined the EU in subsequent enlargements. The countries with the lowest globalization remain outside the EU (as candidates or associated with the EU). This can be seen by analysing the KOF data.

Increasing the level of globalization was undoubtedly a consequence of these two processes (systemic transformation and economic integration) that occurred together. The systemic transformation in these countries had a dual character. It was a transition to a market economy in general, but also to the requirements of the market economy in which the EU functions. These two transformations were strongly conjugated and mutually conditioned (Swadzba, 2007). Therefore, the impact of these processes on the globalization of these countries cannot be considered separately.

The systemic transformation and integration with the EU were the main factors that contributed to the increase in their level of globalization, but they also had an influence on the increasing of the economic growth and socio-economic development. The positive impact of these factors on economic growth resulted from the increase in economic freedom in these countries. The relationship between economic freedom and economic growth are usually of such a nature. Greater economic freedom fosters economic growth (De Hann and Sturm, 2000). The influence of globalization (KOF Index of Globalization) on some indices of economic growth and socio-economic development in EU-11 countries was examined. They are: GDP per capita (EU-28 = 100), GDP per capita (euro), HDI Index, GDP average growth rate and HDI average growth rate. It was analysed by regressing KOF Index of Globalization (2018) as dependent variable against the above-mentioned factors as independent variables. Regression functions (y) and coefficient of determination $\left(\mathrm{R}^{2}\right)$ for these relationships, both for the general globalization index and the economic globalization index, are included in Table 6.

Table 6: Regression function (y) and coefficient of determination $R^{2}$

\begin{tabular}{|c|c|c|}
\hline Correlation & Regression function & $\mathbf{R}^{2}$ \\
\hline Index of globalization (2018) vs. GDP per capita (2017) & $y=1.7015 x-64.69$ & $\mathrm{R}^{2}=0.1361$ \\
\hline Index of economic globalization (2018) vs. GDP per capita (2017) & $y=0.7081 x+16.569$ & $\mathrm{R}^{2}=0.0928$ \\
\hline Index of globalization (2018) vs. GDP (euro) per capita (2017) & $y=682.59 x-40,491$ & $\mathrm{R}^{2}=0.1874$ \\
\hline Index of economic globalization (2018) vs. GDP (euro) per capita (2017) & $y=320.85 x-10,772$ & $\mathrm{R}^{2}=0.1631$ \\
\hline Index of globalization (2018) vs. HDI Index (2017) & $y=0.0035 x+0.5758$ & $\mathrm{R}^{2}=0.0985$ \\
\hline Index of economic globalization (2018) vs. HDI Index (2017) & $y=0.0013 x+0.7493$ & $\mathrm{R}^{2}=0.0572$ \\
\hline Index of globalization (2018) vs. GDP growth rate (1996-2017) & $y=-0.119 x+13.032$ & $\mathrm{R}^{2}=0.0765$ \\
\hline Index of economic globalization (2018) vs. GDP growth rate (1996-2017) & $\mathrm{y}=0.0097 \mathrm{x}+2.7682$ & $\mathrm{R}^{2}=0.002$ \\
\hline Index of globalization (2018) vs. HDI growth rate (1990-2017) & $\mathrm{y}=0.0009 \mathrm{x}+0.5682$ & $\mathrm{R}^{2}=0.0008$ \\
\hline Index of economic globalization (2018) vs. HDI growth rate (1990-2017) & $y=-0.0016 x+0.7664$ & $\mathrm{R}^{2}=0.0093$ \\
\hline
\end{tabular}

Source: calculation by author based on date included in tables 1-5 
The above results show, that there is a correlation between them but it is rather small. In general, the relationship between them is greater in the case of the overall index of globalization than the index of economic globalization. As far as Index of globalization vs. GDP growth rate and Index of economic globalization vs. HDI growth rate are concerned, there are a negative correlation between them (very small). The greatest dependency exists between the level of globalization and GDP per capita. The level of globalization has a very little effect on the average annual GDP growth rate.

It should be also mentioned that in all the cases the $\mathrm{R}^{2}$ is low or even very low. It means that globalization (measured by KOF Index) should not be treated as the main cause factor of economic growth, what is, however, obvious taking into account growth theory.

The correlation between percentage changes in the index of globalization and percentage changes in GDP per capita in EU-11 countries was also examined. It was analysed by regressing the percentage change in the KOF Index of Globalization (1995-2018) as dependent variable against the percentage changes in GDP per capita in PPS (1995-2017) as independent variables. Estimated regression function was $y=0,3366 x+50.994\left(R^{2}=0.0352\right)$. It means, that the thesis about the positive impact of globalization on economic growth in case of EU-11 countries was positively verified.

\section{Conclusion}

Studies on the globalization and economic growth of EU-11 countries allow drawing the following conclusions. Starting from the 1990s, the level of globalization of this group of countries has increased significantly. The largest increase took place in countries where the level of globalization at the starting point was the lowest, and the lowest in the most globalized countries. As a result, the differences between individual countries have significantly diminished. So we can see the convergence also in the sphere of globalization. The increase in the degree of globalization varied throughout the sub-periods. The current level of globalization of these countries is the result of the combined action of both systemic transformations and the process of integration with the EU. The rate of economic growth in these countries is rather high, much higher than in the old EU. As a result, GDP per capita increased significantly in EU-11 countries. The positive impact of globalization on economic growth was noted.

Funding: This research received no external funding

Author Contributions: The author confirms being the sole contributor of this work and approved it for publication.

Conflict of Interest Statement: The author declares that the research was conducted in the absence of any commercial or financial relationships that could be construed as a potential conflict of interest.

\section{References}

Bentley, J. H. (2004). Globalizing history and historicizing globalization. Globalizations, 1(1), 69-81.

Bergh, A. \& Karlsson, M. (2010). Government size and growth. Accounting for economic freedom and globalization. Public Choice, 142(1-2), 195-213.

Caselli, M. (2008). Measuring... What? Notes on some globalization indices. Globalizations, 5(3), 383-404. 
Crafts, N. (2004). Globalisation and economic growth. A historical perspective. The World Economy, 27(1), 4558.

De Haan, J. \& Sturm, J.-E. (2000). On the relationship between economic freedom and economic growth. European Journal of Political Economy, 16(2), 215-241.

Dreher, A. (2006). Does globalization affect growth? Empirical evidence from a new index of globalization. Applied Economics, 10, 1091-1110.

Dreher, A. \& Gaston, N. (2008). Has globalization increased inequality? Review of International Economics, 16(3), 516-536.

Dreher, A., Gaston, N. \& Martens, P. (2008). Measuring globalization - Gauging its consequences. New York: Springer.

Dreher, A., Gaston, N., Martens, P. \& Van Boxem, L. (2010). Measuring globalization - Opening the black box. A critical analysis of globalization indices. Journal of Globalization Studies, 1(1), 166-185.

EBRD. Transition report 2003, 2007, 2009.

Figge, L. \& Martens, P. (2014). Globalisation continues: The Maastricht globalisation index revisited and updated. Globalizations, 11, 875-893.

Gozgor, G. (2018). Robustness of the KOF index of economic globalization. The World Economy, 41(2), 414430.

Grossman, G. \& Helpman E. (2015). Globalization and growth. American Economic Review, 105(5), $100-104$.

Gygli, S., Haelg, F., Potrafke, N. \& Sturm, J-E. (2019). The KOF globalization index - Revisited. The Review of International Organizations, 1-32.

https://ec.europa.eu

Human Development Reports. United Nations Development Programme. Available: http://hdr.undp.org

Hayaloglu, P., Kalayci, C. \& Artan, S. (2015). How does globalization affect economic growth across different income group countries? Eskisehir Osmangazi University Journal of Economics and Administrative Sciences, 10, 119-151.

James, P. \& Steger, M. B. (2012). A genealogy of "Globalization”: The career of a concept. Globalizations, 9(2), 417-434.

Kearney/Foreign Policy. (2001). Measuring globalization. Foreign Policy, 122, 56-65.

KOF Index of Globalization. Available: http://www.globalization.kof.ethz.ch.

Lockwood, B. (2004). How robust is the foreign policy/Kearney globalization index? The World Economy, 27(4), 507-523.

Lockwood, B. \& Redoano, M. (2005). The CSGR globalisation index: An introductory guide. CSGR working paper. Technical report, 155(04).

Martens, P., Castelli, M., De Lombaerde, P., Figge, L. \& Scholte, J. A. (2014). New directions in globalization indices. Globalizations, 12, 217-228.

Martens, P., Dreher, A. \& Gaston, N. (2010). Globalisation, the global village and the civil society. Futures, 42 , 574-582.

Martens, P. \& Raza, M. (2009). Globalisation in the $21^{\text {st }}$ Century: Measuring regional changes in multiple domains. The Integrated Assessment Journal, 9, 1-18.

Martens, P. \& Rotmans, J. (2005). Transition in globalising world. Futures, 37(10), 1133-1144.

Martens, P. \& Zywietz, D. (2006). Rethinking globalization: A modified globalization index. Journal of International Development, 18(3), 331-350.

Potrafke, N. (2015). The evidence on globalisation. The World Economy, 38(3), 509-522.

Samini, P. \& Jenatabadi, H. S. (2014). Globalization and economic growth: Empirical evidence on the role of complementarities. PLoS One, 9(4), 1-7.

Scholte, J. A. (2008). Defining globalisation. The World Economy, 31(11), 1471-1502.

Swadzba, S. (2017). The differences in the level of globalization and its changes in the world. Proceedings of $17^{\text {th }}$ International Scientific Conference Globalization and its socio-economic consequences. Rajecke Teplice, Slovak Republic, 2594-2601.

Swadzba, S. (2007). Integracja i globalizacja a system gospodarczy. Konsekwencje dla Polski. Katowice: Wydawnictwo Akademii Ekonomicznej w Katowicach.

Villaverde, J. \& Maza, A. (2011). Globalization, growth and convergence. The World Economy, 34(6), pp. 952971.

Vujakovic, P. (2010). How to measure globalisation? A new globalisation index (NGI). Atlantic Economic Journal, 38(2), 237-237.

Zagora-Jonszta, U. (2017). Measuring globalization. Advantages and disadvantages of measuring. Proceedings of $17^{\text {th }}$ International Scientific Conference Globalization and its socio-economic consequences. Rajecke Teplice, Slovak Republic, 3037-3044. 